\title{
Swelling studies of camel and bovine corneal stroma
}

This article was published in the following Dove Press journal:

Clinical Ophthalmology

15 September 2010

Number of times this article has been viewed

\section{Turki Almubrad Mohammad Faisal Jamal \\ Khan \\ Saeed Akhtar}

Cornea Research Chair, Department of Optometry, College of Applied Medical Sciences, King Saud University, Saudi Arabia
Correspondence: Saeed Akhtar Cornea Research Chair, Department of Optometry, College of Applied Medical Sciences, King Saud University, PO Box 10129, Riyadh II433, Saudi Arabia

Email akhtars@ksu.edu.sa
Abstract: In the present study we investigated the swelling characteristics of fresh camel and bovine cornea in sodium salt solutions. Swelling studies were carried out at 20 minutes, 14 hours, and 46 hours on five fresh camel and 5 five fresh bovine corneas. During the 20 -minute hydration of fresh corneal stroma was investigated using sodium chloride $(\mathrm{NaCl})$, sodium bicarbonate $\left(\mathrm{NaHCO}_{3}\right)$, sodium acetate $\left(\mathrm{CH}_{3} \mathrm{COONa}\right)$, sodium thiocyanate $(\mathrm{NaSCN})$, and sodium floride $(\mathrm{NaF})$ at 2-minute time intervals. During a 46-hour time period, the hydration study was carried out using $\mathrm{NaCl}(150,300 \mathrm{mM})$ and $\mathrm{NaF}(150 \mathrm{mM})$ at random intervals. The 14-hour study was carried out to assess the rehydration of corneal stroma after 6 hours of drying. During the 20-minute swelling studies in the first 2 minutes the rate of hydration in both camel and bovine corneas was high but gradually reduced in the 2-20-minute period. The rates and levels of hydration of camel and bovine cornea were not significantly different from each other in all the strengths of solutions. During the 46-hour swelling studies, the initial rate of hydration ( $0-2$ hours) of camel and bovine stroma, in all solutions was significantly higher $(Z=0.056)$ compared to hydration during later hours (2-46 hours). Camel stromal hydration (high) in $150 \mathrm{mM} \mathrm{NaCl}$ was significantly higher compared to bovine stromal hydration in the same solution during the 10-24, and 24-46-hour time periods. Rehydration in camel stroma was significantly lower than bovine in $150 \mathrm{mM} \mathrm{NaF}$. The 20-minute study showed that there was no selective affinity for particular ions in camel or bovine corneal stroma. Initial swelling in both corneal and bovine stroma is faster and more prominant compared to later swelling. The swelling in camel cornea is more prominant compared to bovine corneal stroma. This could be due to higher negatively charged keratin sulfate-proteoglycans in the stroma. Lower rehydration in camel cornea suggests stronger leaching of proteoglycans from stroma in $\mathrm{NaF}$.

Keywords: camel, swelling, sodium thiocyanate, sodium bicarbonate, proteoglycans

The cornea and sclera together form the outermost covering of the eye and withstand both internal and external forces on the eye to maintain the shape of the eyeball and to protect the contents from mechanical injury. ${ }^{1,2}$ Approximately $90 \%$ of the cornea consists of stroma which contains collagen fibrils, proteoglycans (PGs) and keratocytes. The collagen fibrils have a uniform diameter and spacing and are organized in tightly packed, parallel-running lamellae. This specific arrangement of collagen fibrils is essential for corneal transparency. ${ }^{3}$

In birds and primates (including humans) corneal collagen fibrils (CFs) are heterotypic, comprising chiefly type I and type $\mathrm{V}$ collagen molecules. ${ }^{4,5}$ The cornea also contains large amounts of type VI collagen, which forms microfibrillar structures by lateral aggregation. ${ }^{5}$ PGs are macromolecular glycoconjugates consisting of specialized polysaccharide chains, glycosaminoglycans (GAGs), which are covalently attached to a protein core. ${ }^{6}$ In the cornea the extracellular matrix contains a class of small interstitial PGs known 
as collagen-binding small leucine-rich repeat proteoglycans (SLRRPs), which carry two types of GAG side chains. The family members lumican, ${ }^{7}$ keratocan, ${ }^{8}$ and mimecan ${ }^{9}$ carry keratan sulfate chains, whereas decorin, ${ }^{10,11}$ biglycan, ${ }^{7,12}$ and versican ${ }^{13}$ carry chondroitin sulfate/dermatan sulfate chains. It is believed that these small leucine-rich repeat proteoglycans (SLRRPs) maintain the uniform organization of collagen fibrils, which is responsible for transparency of the cornea. Swelling of the cornea is believed to be due to an excess of water absorbed by the negatively charged proteoglycans, which results in nonuniform distribution of collagen fibrils.

Unlike other connective tissues, including sclera, the cornea is transparent. It is believed that the endothelium normally acts as a barrier to maintain the ionic composition of the stromal matrix and, more importantly, to maintain optimum hydration. ${ }^{1,14}$ The swelling of corneal stroma in vivo is not manifested because of the presence of a balancing outward directed bicarbonate ion pump located in the corneal endothelial lining at the posterior surface of the stroma. ${ }^{15-17}$ When the stroma swells it loses its transparency. ${ }^{18,19}$ This is due to increased light scattering, which is thought to be caused by a nonuniform distribution of water and disruption of the collagen packing. ${ }^{20}$ Corneal swelling has been studied by placing the corneal stroma in distilled water ${ }^{21-24}$ and bathing solutions with different ionic strengths and pH levels. $^{22}$

Previous swelling studies have been carried out on bovine cornea; ${ }^{22,25}$ however, there has been no study carried out on the camel cornea. Camels are native to hot, sunny, and sandy hot air-blowing climates. Even though these climatic conditions cause dry eyes in most animals, camels have wet eyes. In the present paper we investigate the swelling characteristics of camel cornea and compare this with those of bovine cornea. To achieve our objective, we studied the free swelling of stromal samples in various monovalent sodium salt solutions, eg, $\mathrm{NaCl}$ ( $\mathrm{pH} 7.4,8.4), \mathrm{NaHCO}_{3}(\mathrm{pH} 8.4)$, $\mathrm{CH}_{3} \mathrm{COONa}$ (pH 7.4), NaSCN (pH 7.4), and NaF (pH 7.4) at various ionic strengths.

\section{Materials and method \\ Tissues}

Five camel and five bovine eyes were obtained 6 hours after the slaughter of the animals. The corneas were dissected from the eye and the epithelium and endothelium were gently removed by scraping with a scalpel. Square pieces ( $8 \times 8 \mathrm{~mm}$ side dimensions) of corneal stroma were cut from the central region. Only one sample was taken from each cornea. All the experiments were carried out at room temperature $\left(20-25^{\circ} \mathrm{C}\right)$.

\section{Bathing solution}

Sodium chloride $(\mathrm{NaCl})$, sodium bicarbonate $\left(\mathrm{NaHCO}_{3}\right)$, sodium acetate $\left(\mathrm{CH}_{3} \mathrm{COONa}\right)$, sodium thiocyanate $(\mathrm{NaSCN})$, and sodium floride were used as bathing solutions (Table 1).

\section{Swelling studies}

We carried out 20-minute and 46-hour swelling studies on camel and bovine cornea. The 20-minute study was undertaken to assess the affinity of the different ionic solutions described above towards the corneal swelling. The 46-hour study was carried out in order to make a direct comparison of free swelling characteristics between camel and bovine corneal stroma. Additionally, a 14-hour study was carried out to assess leaching out of proteoglycans from the stroma to the bathing solutions. The difference between hydration and rehydration of the corneal stroma will be the leaching out of PGs from the stroma to the bathing solutions.

\section{0-minute swelling study of stroma obtained from fresh eyes}

Square pieces $(8 \times 8 \mathrm{~mm}$ side dimensions $)$ of corneal stroma were air dried for 3-4 hours and weighed. Immediately after weighing, the samples were kept in $50 \mathrm{~mL}$ of bathing solution (Table 1) of $\mathrm{NaCl}$ ( $\mathrm{pH} 7.4), \mathrm{NaCl}(\mathrm{pH} 8-8.4), \mathrm{CH}_{3} \mathrm{COONa}$ ( $\mathrm{pH} 7.4$ ), $\mathrm{NaSCN}$ (pH 7.4), or $\mathrm{NaHCO}_{3}$ (pH 8-8.4) at $37.5 \mathrm{mM}$, $75 \mathrm{mM}, 150 \mathrm{mM}, 300 \mathrm{mM}$, or $600 \mathrm{mM}$ concentrations separately. The wet weight of the sample was recorded at 2-minute intervals for a 20-minute time period. The samples were removed from the bathing solution and washed with distilled water for a period of 2-3 hours (to remove excess

Table I Solutions used for swelling studies

\begin{tabular}{|c|c|c|c|c|}
\hline Solution & $\mathrm{pH}$ & $\begin{array}{l}\text { Ionic } \\
\text { concentration }\end{array}$ & Buffer & $\begin{array}{l}\text { Study } \\
\text { period }\end{array}$ \\
\hline $\begin{array}{l}\text { Sodium chloride } \\
(\mathrm{NaCl})\end{array}$ & 7.4 & $\begin{array}{l}37.5 \mathrm{mM}, 75 \mathrm{mM} \text {, } \\
\mathrm{I} 50 \mathrm{mM}, 300 \mathrm{mM} \text {, } \\
\text { and } 600 \mathrm{mM}\end{array}$ & $\begin{array}{l}\text { I mM } \\
\text { HEPES }\end{array}$ & $\begin{array}{l}20 \text { minutes; } \\
46 \text { hours; } \\
14 \text { hours }\end{array}$ \\
\hline $\mathrm{NaCl}$ & 8 & $\begin{array}{l}37.5 \mathrm{mM}, 75 \mathrm{mM} \text {, } \\
\mathrm{I} 50 \mathrm{mM}, 300 \mathrm{mM} \text {, } \\
\text { and } 600 \mathrm{mM}\end{array}$ & $\begin{array}{l}\text { ImM } \\
\text { Tris }\end{array}$ & $\begin{array}{l}20 \text { minutes; } \\
46 \text { hours; } \\
14 \text { hours }\end{array}$ \\
\hline $\begin{array}{l}\text { Sodium } \\
\text { bicarbonate } \\
\left(\mathrm{NaHCO}_{3}\right)\end{array}$ & $8-8.4$ & $\begin{array}{l}37.5 \mathrm{mM}, 75 \mathrm{mM} \text {, } \\
\mathrm{I} 50 \mathrm{mM}, 300 \mathrm{mM} \text {, } \\
\text { and } 600 \mathrm{mM}\end{array}$ & none & 20 minutes \\
\hline $\begin{array}{l}\text { Sodium acetate } \\
\left(\mathrm{CH}_{3} \mathrm{COONa}\right)\end{array}$ & 7.4 & $\begin{array}{l}37.5 \mathrm{mM}, 75 \mathrm{mM} \text {, } \\
150 \mathrm{mM}, 300 \mathrm{mM} \text {, } \\
\text { and } 600 \mathrm{mM}\end{array}$ & $\begin{array}{l}\text { ImM } \\
\text { HEPES }\end{array}$ & 20 minutes \\
\hline $\begin{array}{l}\text { Sodium } \\
\text { thiocyanate } \\
(\mathrm{NaSCN})\end{array}$ & 7.4 & & $\begin{array}{l}\text { I mM } \\
\text { HEPES }\end{array}$ & 20 minutes \\
\hline $\begin{array}{l}\text { Sodium Floride } \\
(\mathrm{NaF})\end{array}$ & 7.4 & $\begin{array}{l}150 \mathrm{mM} \text { and } \\
300 \mathrm{mM}\end{array}$ & $\begin{array}{l}\text { ImM } \\
\text { HEPES }\end{array}$ & $\begin{array}{l}20 \text { minutes; } \\
46 \text { hours; } \\
\text { I } 4 \text { hours }\end{array}$ \\
\hline
\end{tabular}


salt) and oven dried at $90-100^{\circ} \mathrm{C}$ for 24 hours. The dry weight of the sample was recorded and hydration calculated using the following formula:

$$
\text { Hydration }=\frac{\text { Wet weight }- \text { Dry weight }}{\text { Dry weight }}
$$

\section{6-hour swelling study of stroma obtained from fresh eyes}

Square pieces $(8 \times 8 \mathrm{~mm}$ side dimensions $)$ of corneal stroma were air dried for 3-4 hours, and their weight was recorded. Immediately after weighing the samples were hydrated in $\mathrm{NaCl}$ (150 mM, pH 7.4), NaF (150 mM, pH 7.4), or NaF (300 mM, $\mathrm{pH}$ 7.4). The wet weight of the sample was recorded at irregular intervals. The samples were removed from the bathing solution and washed with distilled water for a period of 2-3 hours to remove excess salt and then oven dried at $90-100^{\circ} \mathrm{C}$ for 24 hours. The dry weight of the sample was recorded and hydration calculated by the aforementioned formula.

\section{4-hour swelling studies of stroma obtained from fresh eyes}

Square pieces $(8 \times 8 \mathrm{~mm}$ side dimensions) of corneal stroma were air dried for 3-4 hours, and their weight was recorded. Immediately after weighing, the samples were hydrated for 14 hours in $\mathrm{NaCl}$ (150 mM, pH 7.4), $\mathrm{NaCl}$ (300 mM, pH 8-8.4), or $\mathrm{NaF}(150 \mathrm{mM}, \mathrm{pH} 7.4)$ separately and their wet weight monitored at 2-hour intervals. After 14 hours of swelling, the samples were air dried for 6 hours, weighed, then rehydrated in the freshly made bathing solution, as previously described. The samples were weighed at intervals of 2 hours for a total period of 14 hours. After that the samples were placed in water for 2-3 hours to remove excess salt and dried in an oven at $90-100^{\circ} \mathrm{C}$ for 24 hours. The dry weight of the sample was recorded and hydration and rehydration calculated by the formula described earlier.

In the present study, various concentrations of salt solutions were used to assess the variation in swelling of cornea. It has been reported that ' $Q$ ' (fixed charge of proteoglycans) is a function of $\mathrm{pH}$ which is dependent on the concentration of the bathing medium. ${ }^{26}$ The higher the concentration of bathing solutions, the lower the swelling of the cornea.

In previous studies it has been shown that swelling is rapid in the initial hour and slower in the later hours. Considering this information, intervals in the initial hours were chosen rather than later hours to observe the swelling trend in both camel and bovine cornea.

Swelling of the fresh sample is considered as hydration, whereas swelling of the air-dried sample after hydration is considered as rehydration. Nonparametric statistical tests were used to perform statistical analysis of the data and Excel was used for drawing graphs.

\section{Results \\ Change in hydration over 20 minutes at 2-minute intervals}

In both camel and bovine samples, the level of hydration was measured for 20 minutes in $\mathrm{NaCl}(\mathrm{pH} 7.4,8.4)$ (Figures $1 \mathrm{~A}$ and $1 \mathrm{~B}$ ), $\mathrm{NaHCO}_{3}(\mathrm{pH} 8$ ) (Figure 1C), and $\mathrm{NaSCN}(\mathrm{pH} 7.4$ ) (Figure 1D), $\mathrm{CH}_{3} \mathrm{COONa}(\mathrm{pH} 7.4$ ) (Figure 1F) (monitored at 2-minute intervals). In general in all solutions, the swelling of both camel and bovine samples was initially fast but gradually slowed down. The level of hydration was also inversely proportional to the concentration of the solutions ie, the lower the concentration of bathing solution the higher the rate of hydration (Figures 1A to 5), but was overall not significant. Rates and level of hydration of camel and bovine samples were also not significantly different from each other in all the solutions (Table 1). The results showed that there was no selective affinity to any particular ionic solution.

\section{Changes in camel and bovine fresh stromal hydration over a 46-hour period} Hydration in camel stroma

During the first 2 hours, the level of hydration in $150 \mathrm{mM}$ $\mathrm{NaCl}$ (12.20), $150 \mathrm{mM} \mathrm{NaF}$ (10.31) and $300 \mathrm{mM} \mathrm{NaF}$ (9.31) was significantly higher $(Z=0.056)$ compared to hydration during later hours (2-46 hours) in these solutions (Figures 2A and 2B). There was no significant difference in hydration among the solutions from each other during the initial hours ( $0-2$ hours). There was a significant difference in hydration between $\mathrm{NaCl} 150 \mathrm{mM}$ and $\mathrm{NaF} 300 \mathrm{mM}$ between $2-10$ hours. The level of hydration of the corneal stroma increases gradually with increase in time (Figure 2A).

The total hydration of $150 \mathrm{mMNaF}$ at 24 hours and 46 hours was significantly higher compared to $150 \mathrm{mM} \mathrm{NaCl}$. The hydration of $150 \mathrm{mM} \mathrm{NaF}$ at 10 hours, 24 hours, and 46 hours was also higher compared to $\mathrm{NaF} 300 \mathrm{mM}$ (Figure 2C).

\section{Hydration in bovine}

In bovine, as with camel corneal stroma, hydration was also high during the first 2 hours compared to hydration during later hours (2-46 hours) in all solutions (Figure 2A). The rate of hydration gradually reduced as time increased. There was no significant difference in change of hydration among the solutions (Figure 2B). Total hydration at 2 hours, 10 hours, 24 hours and 46 hours was also not significantly different (Figure 2C). 

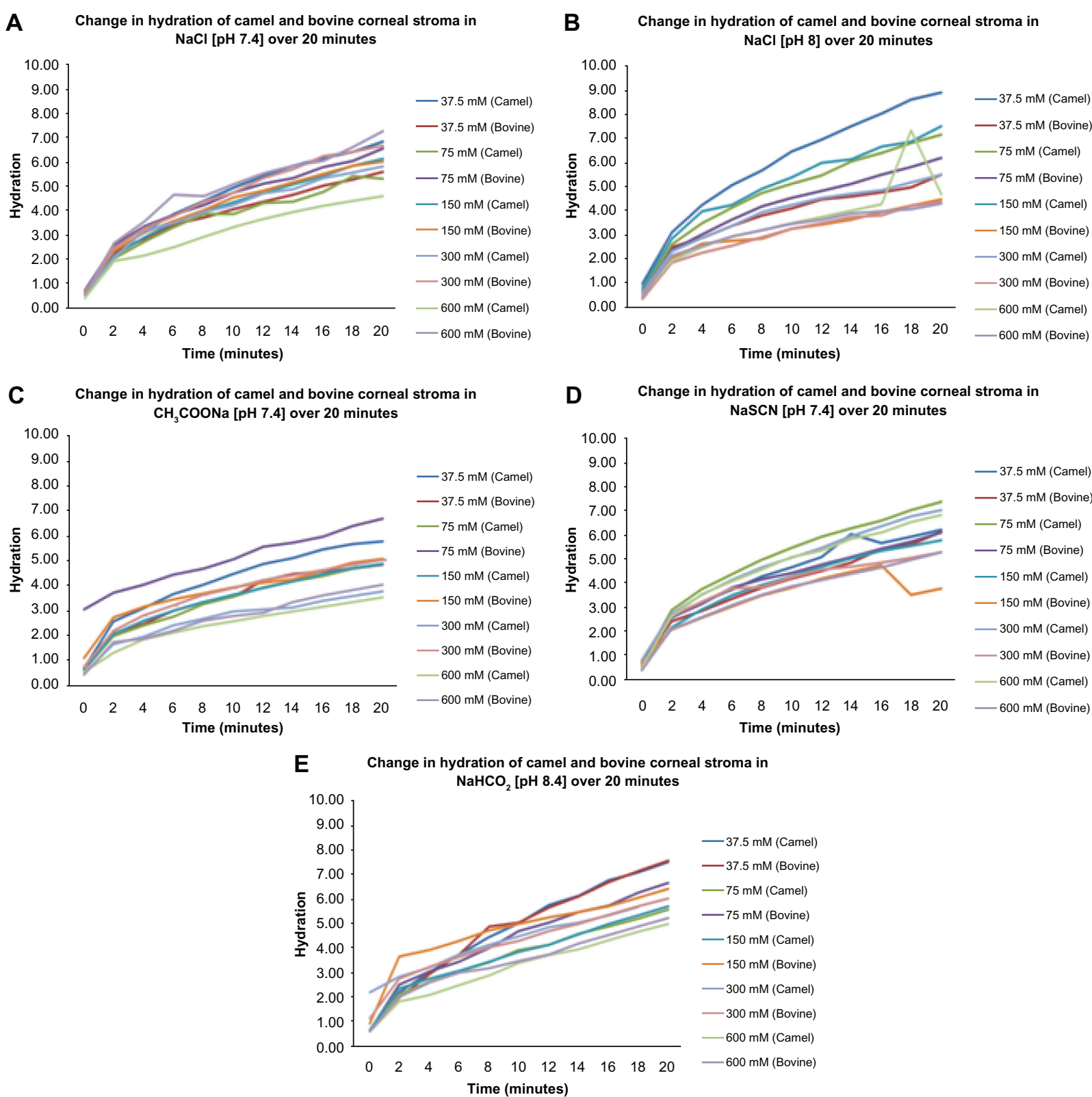

Figure I Change in hydration of camel and bovine corneal stroma in bathing solutions of concentrations $37.5 \mathrm{mM}, 70 \mathrm{mM}, 150 \mathrm{mM}, 300 \mathrm{mM}, 600 \mathrm{mM}$ every $2 \mathrm{minutes}$ over a 20-minute time period; A) $\mathrm{NaCl} \mathrm{pH} \mathrm{7.4;} \mathrm{B)} \mathrm{NaCl} \mathrm{pH} \mathrm{8;} \mathrm{C)} \mathrm{NaHCO}_{3}$; D) $\mathrm{NaSCN}$; E) $\mathrm{CH}_{3} \mathrm{COONa}$.

\section{Comparison between camel and bovine stroma hydration}

There was a significant difference in change in hydration observed between camel and bovine for some solutions. Camel stromal hydration (high) in $150 \mathrm{mM} \mathrm{NaCl}$ was significantly higher compared to bovine stromal hydration in the same solution at 10-24 hours, and 24-46 hours (Figure 2B). At 2-10 and 24 hours, change in hydration was also significantly different between camel stroma hydration in $\mathrm{NaCl}$ and bovine stromal hydration in NaF $300 \mathrm{mM}$ (Figure 2B).

With respect to total hydration, camel corneal stroma imbibes more fluid over 2, 10, 24, and 46 hours compared to bovine stroma. In NaF 300, camel stroma hydration was significantly higher at 10 hours and 24 hours compared to bovine stromal hydration (Figure 2C).

\section{Hydration and rehydration of fresh corneal stroma over a I4-hour period}

\section{at 2-hour intervals}

Hydration $(\mathrm{H})$ and rehydration $(\mathrm{RH})$ in camel stroma

The hydration of corneal stromas from fresh eyes was carried out in the above bathing solutions for 14 hours. At 2-hour intervals hydration levels were recorded as described earlier in the Method section. The initial mean hydration at $0-2 \mathrm{hrs}$, in $150 \mathrm{mM} \mathrm{NaCl}(\mathrm{H}=8.173), 300 \mathrm{mM} \mathrm{NaCl}(\mathrm{H}=8.325)$, and $150 \mathrm{mM} \mathrm{NaF}(\mathrm{H}=7.937)$ was significantly higher $(\mathrm{Z}>0.000)$ 


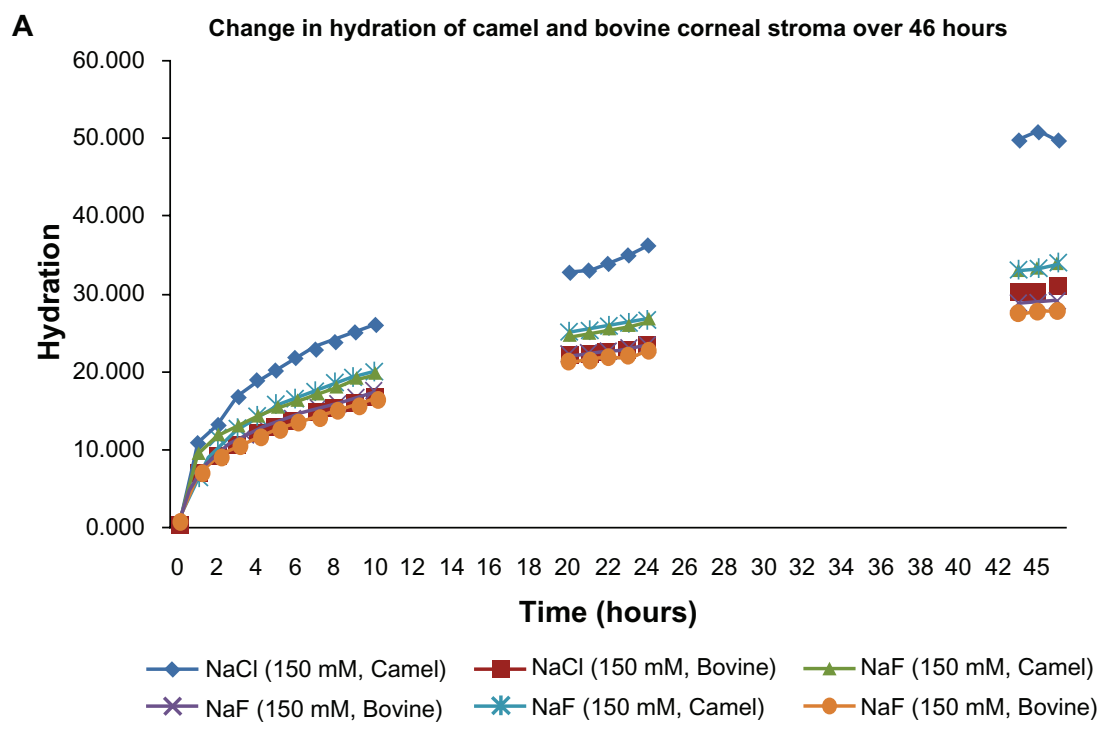

B

Change in hydration during $0-2,2-10,10-24$ and $24-46$ hours

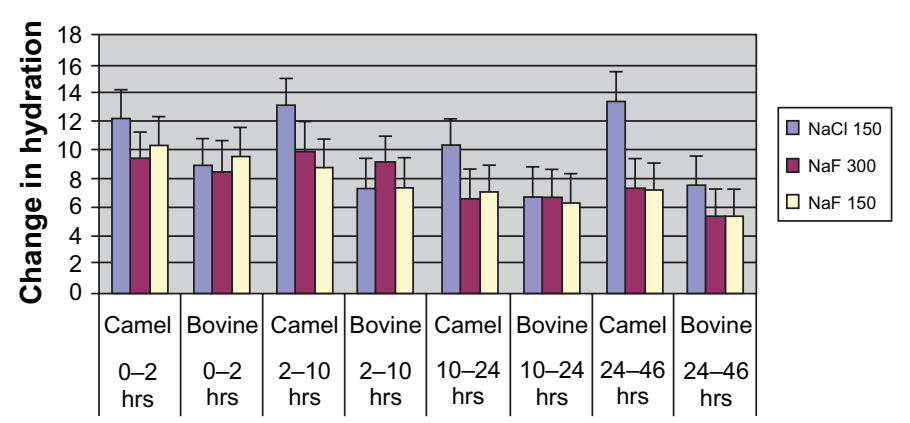

Time period

C

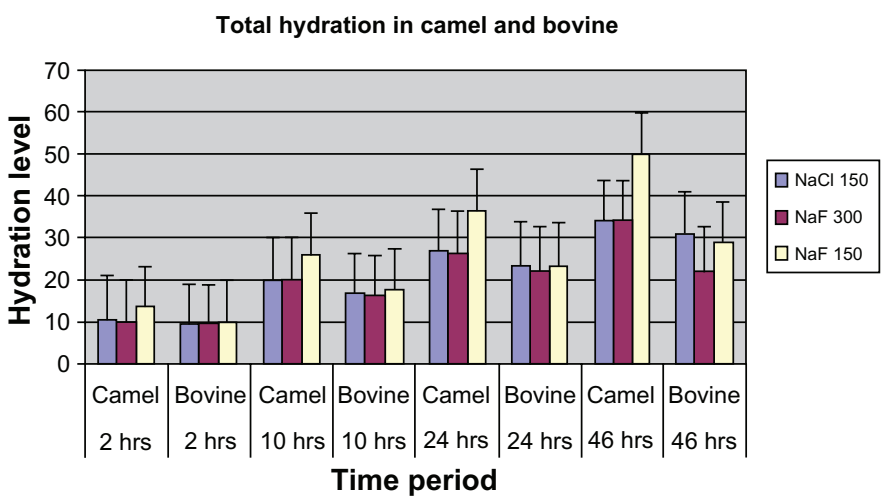

Figure 2 Change in hydration of camel and bovine corneal stroma in bathing solutions $\mathrm{NaCl} \mathrm{pH} 7.4$ (I50 mM), $\mathrm{NaCl} \mathrm{pH} 8.4$ (300 mM), and NaF (I50 mM) over $46 \mathrm{hours}$; A) Gradual change in hydration at 2-hour intervals over a 46-hour time period; B) Mean change in hydration of camel and bovine corneal stroma at 0-2 hours, 2-10 hours, 10-24 hours, and 24-46 hours; C) Total hydration in camel and bovine corneal stroma at 0-2 hours, 2-10 hours, 10-24 hours, and 24-46 hours.

compared to later hydration (2-14 hours) in $150 \mathrm{mM} \mathrm{NaCl}$ $(\mathrm{H}=3.25-0.96), 300 \mathrm{mM} \mathrm{NaCl}(\mathrm{H}=2.94-1.21)$, and $150 \mathrm{mM}$ $\mathrm{NaF}(\mathrm{H}=2.83-0.75)$. The level of hydration among the solutions was not significantly different from each other (Figure 3A).

Following hydration, the samples were air dried for 6 hours and then samples were rehydrated in $\mathrm{NaCl}(150 \mathrm{mM}$ and $300 \mathrm{mM}$ ) and $\mathrm{NaF}(150 \mathrm{mM})$ over a 14-hour period at 2 -hour intervals. The initial mean rehydration of the samples during 0-2 hours in $150 \mathrm{mM} \mathrm{NaCl}(\mathrm{RH}=8.869), 300 \mathrm{mM}$
$\mathrm{NaCl}(\mathrm{RH}=7.452)$ and $150 \mathrm{mM} \mathrm{NaF}(\mathrm{RH}=5.940)$ was significantly higher $(Z>0.000)$ compared to later hydration (2-14 hours) in $150 \mathrm{mM} \mathrm{NaCl}(\mathrm{RH}=2.49-1.09), 300 \mathrm{mM}$ $\mathrm{NaCl}(\mathrm{RH}=2.74-1.09)$, and $150 \mathrm{mMNaF}(\mathrm{RH}=0.65-0.21)$ (Figure 3A). The level of rehydration among the solutions at $0-2$ hours was not significantly different from each other. The level of hydration in $\mathrm{NaF} 150 \mathrm{mM}$, was significantly less compared to $\mathrm{NaCl} 150 \mathrm{mM}$ and $300 \mathrm{mM}$ at 2-4 hours $(Z=0.016)$ and $4-14$ hours $(Z=0.016)$. 
A

Change in hydration of camel and bovine corneal stroma over 14 hours

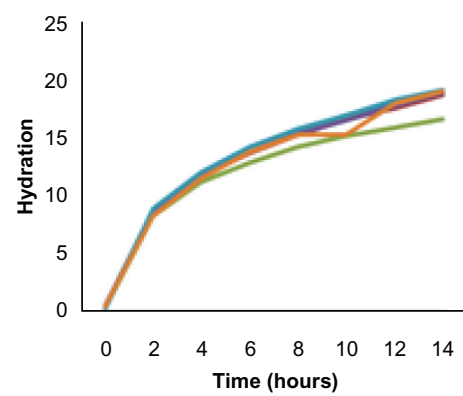

B

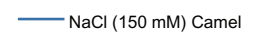

- $\mathrm{NaCl}(300 \mathrm{mM})$ Camel

- NaF $(150 \mathrm{mM})$ Camel

— $\mathrm{NaCl}(150 \mathrm{mM})$ Bovine

— $\mathrm{NaCl}(300 \mathrm{mM})$ Bovine

L NaF (150 mM) Bovine
Change in rehydration of camel and bovine corneal stroma over 14 hours

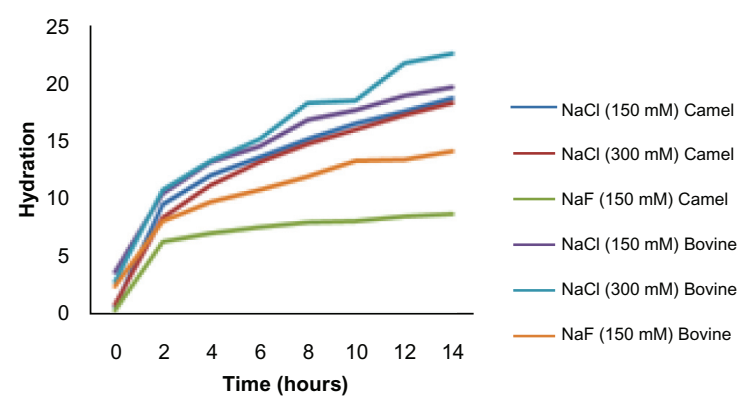

C Change in hydration and rehydration in corneal stroma of camel and bovine

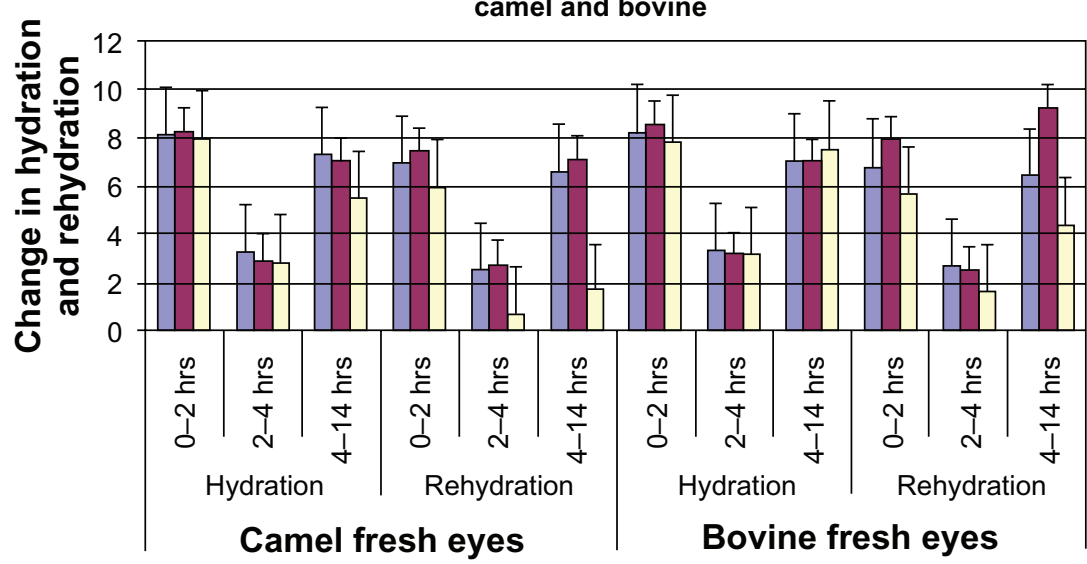

$\square \mathrm{NaCl} 150 \quad \square \mathrm{NaCl} 300 \quad \square \mathrm{NaF} 150$

Figure 3 Change in hydration and rehydration of camel and bovine corneal stroma in bathing solutions $\mathrm{NaCl} \mathrm{pH} 7.4$ (I50 mM), $\mathrm{NaCl} \mathrm{pH} 8.4$ (300 mM), and $\mathrm{NaF}$ (I50 mM) over 14 hours; A) Gradual change in hydration of camel and bovine corneal stroma at 2-hour intervals over a I4-hour time period; B) Gradual change in rehydration of camel and bovine corneal stroma at 2-hour intervals over a 14-hour time period; C) Mean change in hydration and rehydration of camel and bovine corneal stroma at 0-2 hours, 2-4 hours, and 4-14 hours.

The comparison between hydration and rehydration of camel corneal stroma showed that hydration in $150 \mathrm{mM}$ and $300 \mathrm{mM} \mathrm{NaCl}$ was not different from the rehydration in these solutions. But rehydration in $\mathrm{NaF}(150 \mathrm{mM})$ was significantly less than hydration in the same solution. This suggests that PGs might have leached out in $\mathrm{NaF}$ during hydration.

\section{Hydration and rehydration in bovine stroma}

Similar to camel, in bovine the initial hydration at $0-2$ hours, in $150 \mathrm{mM} \mathrm{NaCl}(\mathrm{H}=8.228), 300 \mathrm{mM} \mathrm{NaCl}(\mathrm{H}=8.578)$, and $150 \mathrm{mM} \mathrm{NaF}(\mathrm{H}=7.788)$ was significantly higher ( $Z>0.000)$ compared to later hydration (2-14 hours) in $150 \mathrm{mM} \mathrm{NaCl}, 300 \mathrm{mM} \mathrm{NaCl}$, and $150 \mathrm{mM} \mathrm{NaF}$ (Figure 3B). The level of hydration among the solutions was not significantly different from each other.

The initial rehydration ( $0-2$ hours) of bovine corneal stroma was also higher compared to the later regular 2-hour hydration
(2-14 hours) in all solutions (Figure 3C). During the 2-4-hour period, the rehydration in $\mathrm{NaCl} 150 \mathrm{mM}$ was significantly higher than rehydration in $\mathrm{NaF} 150 \mathrm{mM}$. The rehydration in $\mathrm{NaCl} 150$ and $\mathrm{NaCl} 300 \mathrm{mM}$ was not significantly different from the hydration in the same solutions. But the rehydration in $\mathrm{NaF} 150 \mathrm{mM}$ was significantly reduced compared to hydration in $\mathrm{NaF} 150 \mathrm{mM}$ (Figure 3C).

\section{Comparison of camel and bovine hydration} and rehydration of stroma

Comparison of hydration and rehydration of camel and bovine stroma showed that there was no significant difference between them in $\mathrm{NaCl}(150 \mathrm{mM}, 300 \mathrm{mM})$. The hydration and rehydration of camel stroma in $\mathrm{NaF}$ was significantly less $(Z=0.016)$ than bovine in the same solution at 4-14 hours. This suggests that leaching of PGs is taking place in both corneas but it is occurring more quickly in camel than bovine cornea. 


\section{Discussion}

In the present study we concentrated on passive swelling, because it is driven by gel pressure which is, in turn, generated by electrostatic repulsion between the net fixed negative charges in the stroma. To study passive swelling, we removed the epithelium and endothelium. The epithelium was removed to avoid interference with the determination of stromal sodium concentration because it has a very slow exchanging sodium pool. ${ }^{27}$ The endothelium was removed to inhibit stromal swelling due to the presence of a balancing outward-directed bicarbonate ion pump located in the corneal endothelium. ${ }^{28}$

Swelling studies have been carried out on rabbit, bovine, and human corneal stroma. ${ }^{29-31}$ Corneal stroma has an innate tendency to imbibe fluid and swell; when it swells it loses its transparency. ${ }^{17}$ The ability to swell and the transparency of fresh corneal stroma are both unusual properties for a connective tissue. ${ }^{22,32}$ The corneal stroma has swelling properties in isotonic saline ${ }^{17,22}$ which can be quantitatively explained by the Donnan theory of corneal swelling..$^{33}$ The single variable which regulates all the phenomena associated with the Hodson-Donnan theory of corneal swelling is the cation exchange capacity, Q, of the matrix molecule. Part of the cation exchange capacity of the corneal stroma is donated by the carboxylic and sulphonic acid groups of the glycosaminoglycans $(\mathrm{GAGs})^{33}$ which are associated with collagen fibrils. ${ }^{34}$

Bron $^{35}$ reported that GAGs of the corneal stroma are keratan sulfate (KS; a component, for instance, of the proteoglycans lumican) dermatan sulfate (DS) and chondroitin sulfate (CS) (components of small proteoglycans, decorin). In bovine corneal stroma, the keratan sulfate/chondroitin4-sulfate ratio is higher posteriorly than anteriorly. ${ }^{36,37}$ If this is the case for human cornea, then since keratan sulfate has a higher water affinity than chondroitin-4-sulfate, this could explain, in part, the greater degree of posterior stromal swelling on immersion. ${ }^{35,38}$ This could be the case in our 46-hour comparative study of swelling of camel and bovine corneal stroma. The level of hydration in camel cornea in all solutions was found to be significantly higher compared to bovine cornea. We presume that camel cornea could have a higher $\mathrm{KS} / \mathrm{CS}$ ratio compared to bovine cornea, and swell more than bovine cornea. If there is a higher concentration of KS, then there will be a higher amount of KS-PGs such as lumican, keratocan, and mimican compared to CS-PGs such as decorin.

Results of our 20-minute study suggested that there was no selective affinity for a particular ionic solution during the process of swelling. The results of our 46-hour study showed that camel stroma has a high level of hydration in all solutions and there is no significant difference in levels of hydration among the solutions from each other during the initial period (0-2 hours). This is consistent with the studies of Kinsey and Cogan ${ }^{39}$ and Hedbys ${ }^{40}$ in which it was found that at high hydration $(H>10)$ swelling does not reduce with increases in concentration of bathing solutions. In this condition, a fixed charge of GAGs also increases. It is believed that in camel cornea, high levels of hydration are not affected by the concentration of bathing solution due to the presence of high fixed charge on GAGs.

Our 14-hour study suggested that leaching of PGs takes place in both corneas but occurs at a higher rate in camel than bovine cornea. It has been suggested that there is the possibility of a differential leaching of GAGs from the stroma during prolonged immersion. ${ }^{35}$ Although only around $1 \%$ of keratan sulfate is lost from corneas held in closed culture ${ }^{41}$ a significant loss of proteoglycans from swollen corneas has been recorded by some researchers ${ }^{42,43}$ with a preferential loss of keratan sulfate from edematous rabbit corneas. ${ }^{44}$ Differential loss has not been studied, but a greater loss of GAGs from the anterior stroma could reduce its "swellability" in human cornea. ${ }^{35}$ There may be a high loss of GAGs from the camel cornea which inhibits "swellability".

Further studies are required to investigate the structural and biochemical analysis of proteoglycans in bovine and camel cornea. These studies could involve biochemical, immuno-histochemical, and electron microscopic techniques.

\section{Disclosure}

The authors report no conflicts of interest in this work.

\section{References}

1. Maurice DM. The cornea and sclera. In Davson $\mathrm{H}$, editor. The Eye, Volume 1b, Vegetative Physiology and Biochemistry, 3rd ed. New York, NY; Academic Press. 1984;509

2. Komai Y, Ushiki T. Three dimensional organization of collagen fibrils in human cornea and sclera. Invest Ophthalmol Vis Sci. 1991;32: 2244-2258.

3. Maurice DM. The structure and transparency of the cornea. J Physiol. 1957;136:263-286.

4. Birk DE, Fitch JM, Babiarz JP, Linsenmayer TF. Collagen type I and type $\mathrm{V}$ present in the same fibril in the avian corneal stroma. J Cell Bio. 1988;106:999-1008.

5. MichelacciYM. Collagens and proteoglycans of the corneal extracellular matrix. Braz J Med Biol Res. 2003;36:1037-1046.

6. Hassell JR, Kimura JH, Hasscall VC. Proteoglycan core protein families Annu. Rev. Biochem. 1986;55:539-567.

7. Blochberger TC, Cornuet PK, Hassell JR. Isolation and partial characterization of lumican and decorin from adult chicken corneas. A keratan sulfate. J Biol Chem. 1992;267:20613-20619. 
8. Corpuz LM, Funderburgh JL, Funderbugh ML, Bottomley GS, Prakash S, Conrad GW. Molecular cloning and tissue distribution of keratocan. Bovine corneal keratan sulfate proteoglycan 37A. J Biol Chem. 1996; 271:9759-9763.

9. Funderburgh JL, Corpuz LM, Roth MR, Funderburgh ML, Tasheva ES, Conrad GW. Mimecan, the 25-kDa corneal keratan sulfate proteoglycan, is a product of the gene producing osteoglycin. J Biol Chem. 1997; 272:28089-28095.

10. Kresse H, Hausser H, Schönherr E. Small proteoglycans. Experientia. 1993;49:403-416.

11. Iozzo RV. The biology of the small leucine-rich proteoglycans. Functional network of interactive proteins. J Biol Chem. 1999;274: 18843-18846.

12. Funderburgh JL, Hevelone ND, Roth MR, et al. Decorin and biglycan of normal and pathologic human corneas. Invest Ophthalmol Vis Sci. 1998;39:1957-1964.

13. Yamagata M, Shinomura T, Kimata K. Tissue variation of two large chondroitin sulfate proteoglycans (PG-M/versican and PG-H/aggrecan) in chick embryos. Anat Embryol (Berl). 1993;187:433-444

14. Green K. Corneal endothelial structure and function under normal and toxic conditions. Cell Bio Rn. 1990;25:169-207.

15. Regini JW, Elliott GF, Hodson SA. The ordering of corneal collagen fibrils with increasing ionic strength. J Mol Biol. 2004;336:179-186.

16. Kinsey VE. Spectral transmission of the eye to ultraviolet radiations. Arch Ophthal. 1948;39:508-513.

17. Hodson S, O'Leary D, Watkins S. The measurement of ox swelling pressure by osmometry. J Physiol. 1991;434:399-408.

18. Wigham CG, Turner HC, Ogbuehi KC, Hodson SA. Two pathways for electrogenic bicarbonate ion movement across the rabbit corneal endothelium. Biochim Biophys Acta. 1996;1279:104-110.

19. Elliot GF, Hodson SA. Cornea, and the swelling of polyelectrolyte gels of biological interest. Report Prog Physics. 1998;61:1325-1365.

20. Benedek GB. Theory of transparency of the eye. Appl Opt. 1971;10:459-473.

21. Goodfellow JM, Elliot GF, Woolgar AE. X-ray diffraction studies of corneal stroma. J Mol Biol. 1978:119:237-252.

22. Elliot GF. Measurement of electric charge and ion-binding of protein filaments in intact muscle and cornea, with implication for filament assembly. Biophys J. 1980;32:95-97.

23. Whitburn SB. Structural and swelling studies of normal, dried and extracted corneal stroma. Doctoral thesis, Milton Keynes, UK: Open University; 1981.

24. Sayers Z, Koch MHJ, Whitburn SB, Meek KM, Elliot GF, Harmsen A. Synchrotron X-ray diffraction study of corneal stroma. J Mol Biol. 1982;160:593-607.

25. Hodson S, Kaila D, Hammond S, Rebello G, Al-Omari Y. Transient chloride binding as a contributory factor to corneal stromal swelling in the ox. $J$ Physiol. 1992;450:89-103.
26. Hodson SA. Corneal Stromal Swelling. Prog Retinal Eye Res 1997; 16:99-116.

27. Otori, T. Electrolyte content of rabbit corneal stroma. Exp Eye Res. 1976;6:356-367.

28. Hodson S, Miller F. The bicarbonate ion pump in the endothelium which regulates the hydration of rabbit cornea. J Physiol. 1976; 263:563-577.

29. Dohlman $\mathrm{CH}$, Hedbys BO, Mishima S. The swelling pressure of the corneal stroma Invest Ophthalmol. 1962;1:158-162.

30. Hedbys BO, Dohlman CH. A new method for determination of the swelling pressure of the corneal stroma in-vitro. Exp Eye Research. 1963:2:122-129.

31. Fatt I, Goldstick TK. Dynamics of water transport in the corneal stroma. J Colloid Sci. 1965;20:962-989.

32. Maurice DM. The physical state of water in corneal stroma. In ME Langham (Ed), The cornea: macromolecular organization of connective tissue. Papers from a symposium held in Kyoto, Japan, 1967, under the auspices of the Dept. of Ophthalmology, Osaka University. John Hopkins Press, Baltimore. 1969, pp. 193-204.

33. Hodson S. Why the cornea swells. J Theoret Biol. 1971:33:419-427.

34. Scott JE, Orford CR, Hughes EW. Proteoglycan-collagen arrangements in developing rat tail tendon. An electron microscopical and biochemical investigation. Biochem J. 1981;195:573-581.

35. Bron AJ. Diagnosis of dry eye. Surv Ophthalmol. 2001;45:S221-S226.

36. Bettelheim FA, Plessy B. The hydration of proteoglycans of bovine cornea. Biochim Biophys Acta. 1975;381:203-214.

37. Castoro JA, Bettelheim AA, Bettelheim FA. Water gradients across bovine cornea. Invest Ophthalmol Vis Sci. 1988;29:963-968.

38. Müller LJ, Pels E, Vrensen GF, Muller et al. The specific architecture of the anterior stroma accounts for maintenance of corneal curvature. Br J Ophthalmol. 2001;85:437-443.

39. Cogan DG, Kinsey VE. The Cornea. I. Transfer of water and sodium chloride by osmosis and diffusion through the excised cornea. Arch of Opthal. 1942;27:466-476.

40. Hedbys BO. The role of polysaccharide in corneal swelling. Exp Eye Research. 1961;1:81-91.

41. Møller-Pedersen T, Møller HJ. Viability of human corneal keratocytes during organ culture. Acta Ophthalmol Scand. 1996;74:449-455.

42. Edelhauser HF. Endothelial and stromal response to injury: corneal biophysics workshop. Corneal Biomechanics and Wound Healing NIH. 1989:171-194.

43. Slack JW, Kangas TA, Edelhauser HF, et al. Comparison of corneal preservation media for corneal hydration and stromal proteoglycan loss. Cornea. 1992;11:204-210.

44. Kangas TA, Edelhauser HF, Twining SS, et al. Loss of stromal glycosaminoglycans during corneal edema. Invest Ophthalmol Vis Sci. 1990;31:1994-2002.
Clinical Ophthalmology

\section{Publish your work in this journal}

Clinical Ophthalmology is an international, peer-reviewed journal covering all subspecialties within ophthalmology. Key topics include: Optometry; Visual science; Pharmacology and drug therapy in eye diseases; Basic Sciences; Primary and Secondary eye care; Patient Safety and Quality of Care Improvements. This journal is indexed on Submit your manuscript here: http://www.dovepress.com/clinical-ophthalmology-journal

\section{Dovepress}

PubMed Central and CAS, and is the official journal of The Society of Clinical Ophthalmology (SCO). The manuscript management system is completely online and includes a very quick and fair peer-review system, which is all easy to use. Visit http://www.dovepress.com/ testimonials.php to read real quotes from published authors. 